\title{
EFFECTS OF THINNING ON DIAMETER, HEARTWOOD, DENSITY AND DRYING DEFECTS OF GMELINA ARBOREA
}

\author{
Jonathan Vallejos ${ }^{1}$, Roger Moya ${ }^{1, \wedge}$, Rafael Serrano ${ }^{1}$
}

\begin{abstract}
The effect of three levels thinning intensity in Gmelina arborea plantation on tree diameter, heartwood (diameter and percentage), wood density and drying defects (twist, crook, bow and check) was studied. Wood used for this study was obtained from eight-year-old plantations with thinning intensity of 60, 70 and $80 \%$ of initial density. Nine trees were selected from each trial. Results showed that tree diameter and wood density were similar in thinning intensity of 70 and $80 \%$, but tree diameter from the plantation with $60 \%$ of thinning intensity was lower than plantation of 70 and $80 \%$. Wood density of trees from $60 \%$ thinning intensity plantation was higher than 70 and $80 \%$. Heartwood diameter and its percentage were the highest in $80 \%$ of thinning intensity. But not difference was found between 60 and $70 \%$ in heartwood (diameter and percentage). Finally, drying defects were not affected significantly by thinning intensity.
\end{abstract}

Keyword: Fast-growth, plantation wood, tree morphologic, wood density, wood properties.

\section{INTRODUCTION}

Gmelina arborea (melina) is widely used in commercial reforestation programs in tropical countries for sawn wood production, pulp or bioenergy (Dvorak 2004). Melina has been planted with high densities, ranging from 1111-1600 trees ha ${ }^{-1}$ or low densities, from 625-800 trees ha ${ }^{-1}$ (Serrano and Moya 2012). Thinning operations depended on the owner of the plantation.

Plantation establishment and thinning application to low intensities are intended to reduce competition between trees and affect wood in many different ways (Onyekwelu et al. 2003). Few studies have examined the effects of applying different thinning intensities on wood properties of $G$. arborea. A study conducted by Moya (2004) with trees from plantations near the cutting age with different management, found that low density plantation (lower than 350 trees $\mathrm{ha}^{-1}$ ), showed lower mechanical resistance than plantations with planting densities over 500 trees ha' ${ }^{-1}$. In another study with the same trees, Moya et al. (2008) showed that the level of thinning intensity had a significant effect on the eccentricity and percentage of the pith and these parameters decreased with thinning intensity increasing.

The objective of this study was to establish the effects of thinning intensity applied to Gmelina arborea plantations in Costa Rica on wood properties, specifically the morphological properties of the tree (diameter and heartwood), wood density and the development of drying defects (warp and check) in dried-lumber. The study of above properties in relation to the intensity of thinning can allow an increasing in the lumber quality by applying appropriate thinning.

\footnotetext{
${ }^{1}$ Instituto Tecnológico de Costa Rica, Escuela de Ingeniería en Forestal, PO Box: 159-7050, Cartago-Costa Rica.

^Corresponding author: rmoya@itcr.ac.cr

Received: 02.03.2014 Accepted: 05.08.2014
} 


\section{MATERIALS AND METHODOLOGY}

\section{Trial location and plantation description}

The trial was located in the Rita, Pococí Canton, Province of Limon, Costa Rica (10 $17^{\circ}$ '24" North latitude and $83^{\circ} 46^{\prime} 14^{\prime \prime}$ 'West longitude), a region of tropical wet forest, with annual rainfall between 3116 and $7000 \mathrm{~mm}$ and no dry months. The temperature range varies between 22 and $27^{\circ} \mathrm{C}$ and altitude of the site is between $200-400 \mathrm{~m}$ with flat topography.

Three plantations were sampled at an age of 8 year (Table 1). The initial planting spacing was $3 \times 3 \mathrm{~m}$ (density of 1111 trees $\mathrm{ha}^{-1}$ ). The total area of these three plantations was 1 hectare. The plantations were established through cuttings and bare-root systems, previously produced by seeds.

Although at the time of the establishment it was noted that fertility and topography conditions were similar, after the first year, it was observed that the site with thinning intensity of $80 \%$ showed low fertility and a higher mortality in relation to other thinning intensities (Table 1). After its analysis, it was found that low fertility was attributed to low calcium content. The previous use of the site where the three plantations were located was banana plantation. Weed and basal sprouts in the stumps of un-thinned trees were controlled manually during the growing of the plantation.

Table 1. Thinning intensity applied in trial plantation of Gmelina arborea.

\begin{tabular}{|l|c|c|c|}
\hline \multicolumn{1}{|c|}{ Parameter } & Trial 1 & Trial 2 & Trial 3 \\
\hline Thinning intensity & $60 \%$ (TI-60) & $70 \%$ (TI-70) & $80 \%$ (TI-80) \\
\hline Thinning type & $\begin{array}{c}\text { Systematic- } \\
\text { selective }\end{array}$ & Selective & Selective \\
\hline Previous thinning & $\begin{array}{c}\text { An intensity of 35\% } \\
\text { at 3-yr-old and 30\% } \\
\text { at 6-yr-old. Initial } \\
\text { mortality was 2,2\%. }\end{array}$ & $\begin{array}{c}\text { An intensity of 35\% } \\
\text { at 3- and 6-yr-old. } \\
\text { Initial mortality was } \\
2,8 \% .\end{array}$ & $\begin{array}{c}\text { An intensity of } 40 \% \\
\text { at 3- and 6-yr-old. } \\
\text { Initial mortality was } \\
4,2 \% .\end{array}$ \\
\hline DBH (cm) & 27,69 & 34,28 & 33,91 \\
\hline $\begin{array}{l}\text { Density at sampled } \\
\text { time (trees/ha) }\end{array}$ & 366 & 302 & 175 \\
\hline $\begin{array}{l}\text { Basal area at sampled } \\
\text { time ( } \mathrm{m}^{2} / \text { ha) }\end{array}$ & 22,29 & 28,33 & 16,22 \\
\hline $\begin{array}{l}\text { Volume at sampled } \\
\text { time ( } \mathrm{m}^{3} / \text { ha) }\end{array}$ & 207,08 & 255,49 & 150,99 \\
\hline
\end{tabular}

In relation with thinning intensity applied, the pruning was done in all trials equally. It was applied to a 3 meters height in the third year and 5 meters in the second thinning (6 years). The company (ENVACO S.A.) had 3 different trials with 3 different thinning intensities (Table 1) whose purpose was to achieve an optimal number of trees per hectare at rotation shift or age of harvest. Two thinning were applied at ages 3 years and 6 years in all trials to achieve the desired thinning intensity (Table 1).

\section{Tree selection and sampling}

Firstly, two circular plots of $100 \mathrm{~m}^{2}$ were established on each trial for plantation characterization (Table 1) and not for sampling trees. Diameter at breast height (DBH) and total height using a clinometer for all individuals within the plot was measured. Subsequently, the diameter, average height, basal area and timber volume were calculated for each trial (Table 1). The selection of trees to be sampled followed the methodology proposed by Moya and Muñoz (2010), which involves drawing up a cumulative frequency distribution of DBH. Then the distribution was divided into three terciles. Three trees were selected at random from each tercil, resulting in a total of nine trees per trial. The trees were selected from the total area of the thinning trial. Trees with straight trunks, regular branching, and no disease or pest symptoms were felled. A cross-sectional sample of $3 \mathrm{~cm}$ wide was taken at 1,3 $\mathrm{m}$ in height (at DBH). Afterwards, two stem sections from DBH to 3,8 $\mathrm{m}$ high and from 3,8 to $6,3 \mathrm{~m}$ high were obtained from each tree (with 2,50 $\mathrm{m}$ in length). The North-South direction was marked on each stem cross-section and two logs for later identification in the laboratory. 


\section{General properties and specify gravity determination}

General properties of trees determined were: $\mathrm{DBH}$, heartwood diameter and heartwood percentage (heartwood diameter/total diameter expressed as a percentage). These properties were measured in the cross section taken from the DBH. On each disc, a cross-sectional line was drawn from north to south passing through the pith and another was marked perpendicular to the first line, from east to west. Total diameter, diameter without bark, and heartwood diameter (Figure 1 in Moya and Muñoz 2010), when it was different, it was measured on a cross-sectional line drawn in two directions (north-south and east-west). Averages for all diameters were calculated as the average of two cross-sectional measurements on each stem section. Next, complete and heartwood cross-sectional areas were calculated as a geometric circle.

SG was calculated as the oven-dry weight divided by volume in green condition and it was determined at 4 different distances from the pith: $0-25 \%, 25-50 \%, 50-75 \%$ and $75-100 \%$. A $3 \mathrm{~cm}$ wide block was cut along the center (including the pith) of each disk and divided into two sub samples (cut in half) for studying the SG. SG was determined using both sub samples. The volume of each sample was defined as the volume of water it displaced when submerged, according to ASTM D2395-02 standards (ASTM 2003). The oven-dry weight was determined after that wood sample was dried for 24 hours at $103^{\circ} \mathrm{C}$.

\section{Drying defects determination}

To evaluate the defects of drying, 18 logs of each thinning treatment ( $2 \operatorname{logs}$ per tree sampled) were sawn. Before sawing the log, the diameter from north-south was marked. Logs were sawn into 2,5 cm-thick boards and these were cut parallel from north-south. Then the boards were edged. Each board was properly identified and coded. All boards were classified according to the grain pattern of the cross section: flat or tangential sawn, radial sawn, rift sawn. Green lumber was stacked in packages $(1 \mathrm{~m}$ wide, 1,3 $\mathrm{m}$ high, and $3,3 \mathrm{~m}$ long). Cross-section pieces of 2,5 x 2,5 cm were used to separate the samples. One pile was made for air-drying, where the wood was left piled in the open, and protected from the sun and the rain. Air-drying was performed in Cartago, province of Costa Rica $\left(9^{\circ} 50^{\prime} 59^{\prime \prime} \mathrm{N}, 83^{\circ} 54^{\prime} 37^{\prime \prime} \mathrm{W}\right)$. The site has an altitude of $1380 \mathrm{~m}$ with an annual temperature between 15 and $24{ }^{\circ} \mathrm{C}$ and an average precipitation of $1563,5 \mathrm{~mm}$. The air-drying was carried out from March to November and the final moisture content of dried-lumber was $16 \%$.

Each board was evaluated before (green condition) and after natural-drying to determine the presence of defects such as warp and checking. The method suggested by Salas and Moya (2014) was used to evaluate drying defects. The boards were measured for maximum bent, corrugated, and warp on a flat table. The following procedure was used for warp measurement: 1) Each piece was positioned on a flat table to examine the extent of each warp type. 2) When the warp was very small the meaningful determination seemed insignificant, a judgment of "no warp" was assigned. 3) The measurement for warp presence was made through the insertion of a calibrated wedge. With the wedge inserted to a point of mild refusal, the measurement was made by reading the calibrated vertical face of the wedge. The values of drying defects were reported as magnitude of the defect in $\mathrm{mm}$ in green condition and after natural drying.

\section{Statistical analysis}

The assumptions of normal distribution, variance homogeneity and absence of extreme data of general properties, specify gravity and drying defects were verified using the SAS System PROC UNIVARIATE procedure Version 8.1 for Windows (SAS Institute 1997). Afterwards, the values of diameter at breast height (DBH), heartwood diameter and heartwood percentage were compared with thinning intensity by ANOVA, where $\mathrm{DBH}$, heartwood diameter and heartwood percentage were dependent variables; thinning intensity was the independent variable. Drying defect values before and after drying in each thinning intensity was analyzed by ANOVA too. The average differences were analyzed by Tukey test with 0,01 significance in order to find which treatments varied. SAS 8.1 (SAS Institute Inc., Cary, N.C.) and STATISTICA 9.1 Windows programs were used for both the analyses. A mixed linear model was used in the analysis of variance of specify gravity (Equation 1). The model included the following sources of variation: thinning intensity (TI) as fixed effect, distance of pith (D) as the random effect and the interactions between thinning intensity and distance of pith (D) (Equation 1). 


$$
Y_{i j}=\mu+T I_{i}+D_{j}+T I^{*} D_{i j}+e_{i j}
$$

where $Y_{i j}$ is the single observation of specify gravity of the ij-tree, $\mu$ is the overall mean, TI is the $\mathrm{i}_{t h}$-thinning intensity as fixed effect, $\mathrm{D}$ is $\mathrm{j}_{t h}$-distance of pith as fixed effect and $\mathrm{D}^{*} \mathrm{TI}_{i j}$ is the random interaction between the $i$ thinning intensity, the $j$-distance of pith and $\varepsilon_{i j}$ is the residual random effect. The GLM procedure from SAS (SAS Institute 1997) was applied to estimate the significance of sources of variation. The difference between average of specify gravity were conducted by CONTRACT statement procedure from SAS.

\section{RESULTS}

\section{General properties}

Trees from the TI-60 treatment showed smaller diameter than TI-70 and TI- 80 and diameter of TI-70 treatment did not produce statistically difference with TI- 80 intensity (Figure 1a). Regarding the heartwood, the diameter of this tissue was the largest diameter in TI- 80 and TI-70 and TI-60 produced the smallest diameter, but without statistical difference with TI-70 (Figure 1b). According to the percentage of heartwood in TI- 80 showed the highest percentage of heartwood and statistically different to the other intensities studied, of which there were no differences between them (Figure 1c).
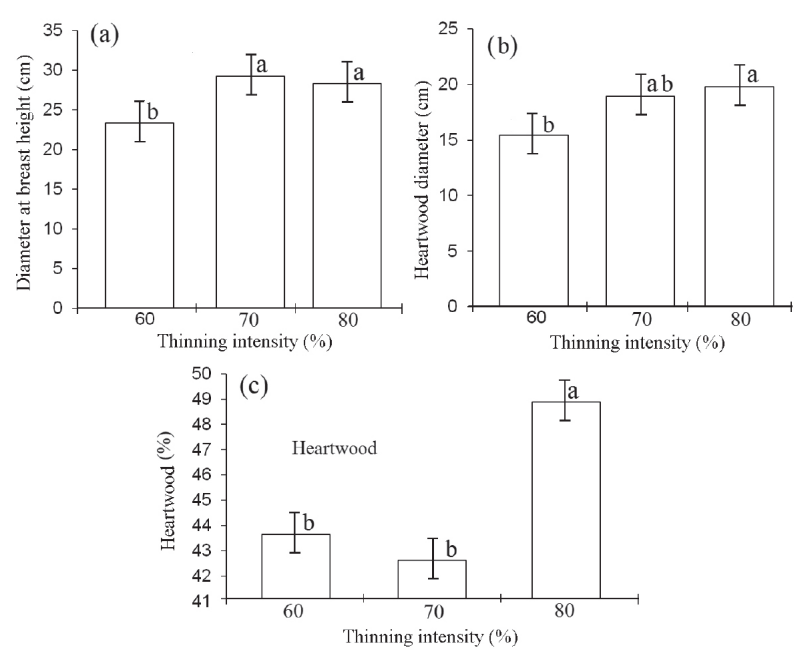

Figure 1. General properties of Gmelina arborea trees in three different thinning intensities: a) diameter at breast height $b$ ) heartwood diameter and c) heartwood percentage.

\section{Specify gravity}

The average specific gravity and its variation are detailed in figure 2. It shows that the variation was from 0,29 to 0,42 , with lower values were found near to pith and the highest values for the wood near the bark, indicating an increase in the pith to bark direction (Figure $2 b$ ). TI-60 produced trees with specific gravity values statistically greater than the average (Figure 2a), as for the different distances relative to the pith (Figure 2b). TI-70 and TI- 80 produced trees with a similar specific gravity values (Figure $2 \mathrm{a}$ ) and at the different distances relative to the pith (Figure 2b). 

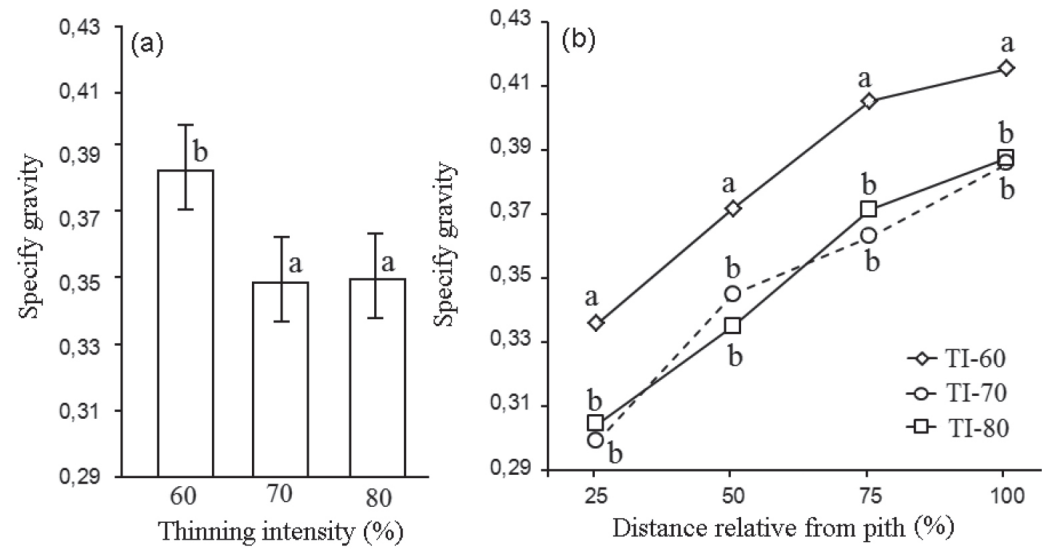

Figure 2. Specific gravity of Gmelina arborea trees in three different thinning intensities:

a) average in diameter at breast height $b$ ) in relation to distance relative from pith.

\section{Drying defects}

Table 2 presents the difference of defects (warp and checking) found in the tables before and after drying for each thinning intensity for each sawing pattern. In the case of twist, it was found that only showed an increase of the defect after drying in rift sawn boards from plantation trees with TI-80. Crook, meanwhile, was the defect where more significant differences occurred, but the advantage of this defect is that it decreases after drying. Evaluation of edge 1 of the board of this defect recorded differences in boards from a plantation trees managed with TI-70 on boards with rift and tangential sawn. On the edge 2 of the board, meanwhile, showed a significant decrease in rift sawn boards from trees in a plantation managed with TI-60 and tangential sawn boards from tree plantation drive with TI-70. Bow was other defect with little variation in the timber before and after drying and again has the advantage that this defects to decrease with drying (Table 2). Significant difference was found only in rift sawn boards from plantation trees with TI-60 and TI-80.

Table 2. Drying defects (warp and checking) before and after air-drying in Gmelina arborea boards from three different thinning.

\begin{tabular}{|c|c|c|c|c|c|c|c|c|c|}
\hline \multirow{2}{*}{ Drying defects } & \multicolumn{3}{|c|}{ Rift sawn boards } & \multicolumn{3}{|c|}{ Radial sawn boards } & \multicolumn{3}{|c|}{ Tangential sawn boards } \\
\hline & TI- 60 & TI-70 & TI- 80 & TI- 60 & TI-70 & TI- 80 & TI-60 & TI-70 & TI- 80 \\
\hline $\begin{array}{l}\text { Twist } \\
(\mathrm{mm})\end{array}$ & $4,50 \Rightarrow 4,50^{\mathrm{ns}}$ & $3,75 \Rightarrow 4,38^{\mathrm{ns}}$ & $1,75 \Rightarrow 4 * *$ & $3,67 \Rightarrow 3,50^{\mathrm{ns}}$ & $2,38 \Rightarrow 2,95^{1 \mathrm{~ns}}$ & $3,25 \Rightarrow 2,68^{\text {ns }}$ & $3,80 \Rightarrow 4,35^{\mathrm{ns}}$ & $3,68 \Rightarrow 3,60^{\mathrm{ns}}$ & $3,73 \Rightarrow 4,36^{\text {ns }}$ \\
\hline $\begin{array}{l}\text { Crook in board } 1 \\
(\mathrm{~mm})\end{array}$ & $2 \Rightarrow 1^{11 s}$ & $3,50 \Rightarrow 0,50^{*}$ & $2 \Rightarrow 1^{1 \mathrm{ss}}$ & $2,83 \Rightarrow 1^{* *}$ & $3,75 \Rightarrow 2^{* *}$ & $2,23 \Rightarrow 1^{*}$ & $2,33 \Rightarrow 1,20^{\mathrm{ns}}$ & $3,41 \Rightarrow 1,43^{* *}$ & $2,17 \Rightarrow 2,24^{\text {1s }}$ \\
\hline $\begin{array}{c}\text { Crook in board } 2 \\
(\mathrm{~mm})\end{array}$ & $4 \Rightarrow 1^{* *}$ & $3 \Rightarrow 1,50^{\mathrm{ns}}$ & $0,70 \Rightarrow 1,00^{\mathrm{ns}}$ & $2,33 \Rightarrow 0,67^{*}$ & $3,45 \Rightarrow 1,10^{* *}$ & $2,33 \Rightarrow 0,67^{*}$ & $2,70 \Rightarrow 1,55^{\mathrm{ns}}$ & $3,46 \Rightarrow 1,22 * *$ & $2,41 \Rightarrow 1,74^{\mathrm{ns}}$ \\
\hline Bow (mm) & $5 \Rightarrow 1^{* *}$ & $13,5 \Rightarrow 12,0^{\mathrm{ns}}$ & $7,00 \Rightarrow 1,00^{* *}$ & $5,67 \Rightarrow 4,67^{1 \mathrm{~ns}}$ & $5,30 \Rightarrow 4,70^{\mathrm{ns}}$ & $5,67 \Rightarrow 4,67^{\mathrm{ns}}$ & $11,35 \Rightarrow 8,95^{\mathrm{ns}}$ & $9,83 \Rightarrow 7,5^{\mathrm{ns}}$ & $8,10 \Rightarrow 6,05^{1 \mathrm{~ns}}$ \\
\hline Check (mm) & $0 \Rightarrow 0^{\mathrm{ns}}$ & $0 \Rightarrow 0^{\mathrm{ns}}$ & $2 \Rightarrow 2^{1 s}$ & $1 \Rightarrow 1^{\mathrm{ns}}$ & $2,6 \Rightarrow 2,5^{\mathrm{ns}}$ & $1 \Rightarrow 1^{\mathrm{ns}}$ & $0,9 \Rightarrow 0,6^{\mathrm{ns}}$ & $0,91 \Rightarrow 0,71^{\mathrm{ns}}$ & $1,24 \Rightarrow 1,14^{\text {ns }}$ \\
\hline
\end{tabular}

Legend: TI: Thinning intensity. Before drying value $\Rightarrow$ After drying value, ${ }^{\text {ns. }}$. No statistics difference between the value before and after drying, * statistically significant with 95\% confidence between the value before and after drying and ** statistically significant with confidence $99 \%$ between the value before and after drying.

Finally, the presence of check was not affected by the drying of wood in any thinning intensities applied, since in any board showed significant differences in the timber before and after drying (Table 2). 


\section{DISCUSSION}

As expected a lower intensity of thinning (TI-60) had the lowest diameter (Figure 1a). This difference can be explained from different aspect in a number of way three. First, in thinned stands, there is less competition. Un-thinned stands exhibiting high levels of inter-tree competition have often failed to increase diameter growth in residual trees. Trees that have experienced less competition tend to add more sapwood basal area with equal amounts of foliage biomass (Morataya et al. 1999). After crown closure, foliage per tree changes little even when height growth continues (due to crown recession and lack of lateral crown expansion) (Onyekwelu et al. 2003). As a result, un-thinned or late thinned plantations produce tall, spindly trees with little foliage relative to their size (Gspaltl et al. 2013). Between a tall tree and a shorter one (in a younger stand), the taller tree must produce more sapwood volume in order to sustain the similar growth rate in diameter, because this volume is distributed over a larger surface (Morataya et al. 1999). Besides, the crown development increases light use efficiency, giving a large diameter (Gspaltl et al. 2013).

As second, the difference can be explained by physiological changes of the tree after thinning (Ginn et al. 1991), significant physiological changes due to thinning and generally observed only in the lower crowns where leaf physiology was found to resemble that of upper crown leaves. In a thinned trial, lower and upper crown photosynthesis and needle conductance did not differ significantly. This is in contrast to the un-thinned trial where both light saturated photosynthesis and leaves conductance were substantially decreased in the lower crown. The increase in crown size and the ability (physiologically) of lower crown foliage to take advantage of the increased light following thinning are likely the major factors resulting in the increased growth of diameter following thinning. High density (more trees) presents a reduction of crown photosynthetic production and begins to limit the amount of water and nutrients absorbed by each individual, due to the lack of root development, resulting in a reduction in diameter with low plantation thinning intensities (Ginn et al. 1991).

Even though, the previous theories can explain the difference that occurs in the TI-60 treatment with other two intensities, these theories cannot be applied to TI-70 and TI-80, because planting densities at sampled time are different from each other (302 and 175 trees $^{-1} a^{-1}$, respectively), the trees diameter have no statistical difference between them. Probably the low fertility found at the site of the plantation with TI- 80 did not allow the potential development of the trees at that site; in fact it was proven by higher mortality in the most thinned site (Table 1). Also, it is possible that there are not significant differences between TI-70 and TI-80 because the largest diameter increments have been reached at TI-70 and the trees were enough spaced where subjected to TI-70.

Heartwood diameter increases with increasing of tree diameter (Díaz-Bravo et al. 2012, Taylor et al. 2002), which was found in the present study. Trees from TI-70 and TI-80 produced a greater diameter relative to lower thinning intensity (TI-60) (Figure 1a). This is because at high thinning intensities larger diameter trees develop, and therefore larger heartwood diameter (Morataya et al. 1999, Gspaltl et al. 2013).

Some studies on Gmelina arborea confirm these results, but in others the results are contradictory. For example Moya (2004) did find a difference in the diameter of the heartwood, but in the case of the percentage found no difference in plantations with 3 types of management (intensive, intermediate and unmanaged).

Specific gravity values obtained (Figure 1e) are consistent with those reported by other studies in Costa Rica (Moya 2004) and other countries such as Nigeria (Akachuku 1985, Hughes and Alburquerque-Sardinha 1975), Venezuela (Espinoza 2004). Also, as expected for this species, trees from low thinning intensity plantations (TI-60) produced higher average density (Figure 1a) and in the radial direction (Figure 1b) in relation to plantation trees with TI-70 and TI-80 (Figure 2a). A low intensity of thinning produces changes in the anatomical structure of the wood, specifically because an increase in the cell wall occurs, the diameter and the vessels frequency decreases (Moya and Tomazello 2009, Moya et al. 2007). These anatomical properties and density in G. arborea occurs because the growth rate declines by high competitions between tress (Hughes and Esan 1969, Moya and Tomazello 2009, Ohbayashi and Shiokura 1989). 
In all applied intensities an increased density with distance from the pith was found (Figure 2b). In general for many species increase in basic density occurs with tree age or in bark-pith direction (Zobel and Van Buijtenen 1989). This change occurs by tree aging, modifications on the woody cells were produced (Moya et al. 2007, Moya and Tomazello 2009).

Other drying defects (twist, bow and check) were scarcely affected by thinning intensity in different grain pattern (Table 2). Contrary to results reported by Moya and Muñoz (2008), Moya et al. (2013) and Salas and Moya (2014) for G. melina lumber. This condition could be associated to the drying method (Klaiber and Seeling 2004), schedules (Salas and Moya, 2014), presence of juvenile wood (Zobel and Sprague 1998), growth stresses in the tree (Archer 1986) and anatomical variation (Moya and Muñoz 2008).

Although it was noted that the intensity of the applied thinning produces alteration in the presence or absence of drying defects (Zobel and Van Buijtenen 1989), the results of this study show otherwise. Possible causes were pointed out above; however special reference should be made for the presence of juvenile wood. Moya and Tomazello (2009) indicated that the approximate age of the termination of juvenile wood in $G$. arborea ends at age 6 , so that the trees sampled ( 8 years old), have a high percentage of this type of wood. Juvenile wood has a high incidence of defects (Zobel and Sprague 1998), so presumably it does not allow management intensity reflects the development of drying defects.

\section{CONCLUSIONS}

Some changes in DBH (Figure 1a), diameter and percentage of heartwood (Figure 1b and 1c), basic density (Figure 2) and drying defects (Table 2) are presented when different thinning intensity is applied. Then this silvicultural practices help to control wood properties in the tree. For example in Gmelina arborea wood is important basic density, then high thinning intensity will be produced wood with lower values of this parameters, but large trees with high heartwood content will be produced. Another important aspect on silvicultural implications is that thinning intensity increment the plantation productivity, but basic density will decreases, but boards with best quality but will increase, which probably means better productivity of plantations. If productivity of plantations is a key consideration for it's final use, then the gain or loss should be considered.

\section{ACKNOWLEDGEMENTS}

The authors wish to thank to Vicerrectoría de Investigación y Extensión from Instituto Tecnológico de Costa Rica. Thanks to ENVACO Forestal for supplying the wood samples for this study.

\section{REFERENCES}

Akachuku, A.E. 1985. Intra-annual variation in wood density in Gmelina arborea from X-ray densitometry and its relations with rainfall. Tree Ring Bulletin 45: 43-55.

Archer, R.R. 1986. Growth Stresses and Strains in Trees. Springer-Verlag, New York.

ASTM International. 2003. Standard test methods for specific gravity of wood and wood-based materials. Standard D2395-02, West Conshohocken, PA.

Díaz Bravo, S.; Espinosa, M.; Valenzuela, L.; Cancino, J.; Lasserre, J. P. 2012. Efecto del raleo en el crecimiento y algunas propiedades de la madera de Eucalyptus nitens en una plantación de 15 años. Maderas: Ciencia y Tecnología 14(3): 373-388.

Dvorak, W.S. 2004. World view of Gmelina arborea: opportunities and challenges. New Forest 28: $111-126$ 
Espinoza, J. 2004. Within-tree density gradients in Gmelina arborea in Venezuela. New Forests 28: 309-317.

Ginn, S.E.; Seiler, J.R.; Cazell, B.H.; Kreh, R.E. 1991. Physiological and growth responses of eight-year-old loblolly pine stands to thinning. Forest Science 37:1030-1040.

Gspaltl, M.; Bauerle, W, Binkleyc, D.; Sterba, H. 2013. Leaf area and light use efficiency patterns of Norway spruce under different thinning regimes and age classes. Forest Ecology and Management 288: 49-59.

Hughes, J.F.; ESAN, D. 1969. Variation in some structural features and properties of Gmelina arborea. Tropical Science 11: 23-37.

Hughes, J.F.; Alburquerque-Sardinha, R.M. 1975. The application of optical densitometry in the study of wood structure and properties. Journal of Microscopy 104: 91-103.

Klaiber, V.; Seeling, U. 2004. The influence of drying method on the warp behavior or Norway spruce (Picea abies (L.) Karst.) sawn timber. Forest Products Journal 54(4):79-87.

Morataya, R.; Galloway, G.; Berninger, F.; Kanninen, M. 1999. Foliage biomass - sapwood (area and volume) relationships of Tectona grandis L.F. and Gmelina arborea Roxb.: silvicultural implications. Forest Ecology and Management 113: 231-239.

Moya, R. 2004. Effect of management treatment and growing regions on wood properties of Gmelina arborea in Costa Rica. New Forests 28: 325-330.

Moya, R.; Araya, L.; Vilchez, B. 2008. Variation in the pith parameter of Gmelina arborea trees from fast growth plantations in Costa Rica. Annals Forest Science 65(6): 612-621.

Moya, R.; Muñoz, F.J. 2008. Wet Pockets in kiln-dried Gmelina arborea lumber. Journal of Tropical Forest Science 20: 48-56.

Moya, R.; Muñoz F. 2010. Physical and mechanical properties of eight species from fast-growth plantation in Costa Rica. Journal of Tropical Forest Science 22(3): 317-328.

Moya, R.; Tomazello, M.; Canessa, E. 2007. Fiber morphology in fast growing Gmelina arborea plantations. Maderas y Bosques 13(2): 3-13.

Moya, R.; Tomazello, M. 2009. Wood density variation and tree ring demarcation in Gmelina arborea trees using x-ray densitometry. Cerne 15: 92-100.

Moya, R.; Urueña, E.; Salas, C.; Muñoz, F.; Espinosa, O. 2013. Kiln drying behavior of lumber from ten fast-growth plantation species in Costa Rica. Wood Material Science and Engineering 8: 37-45.

Onyekwelu, J.C.; Biber, P.; Stimm, B. 2003. Thinning scenarios for Gmelina arborea plantations in southwestern Nigeria using density management diagrams. Food, Agriculture \& Environment 1(2): 320-325.

Ohbayashi, H.; Shiokurat, H. 1989. Anatomical structure of fast-growing tropical tree species whit differing growth rates. IAWA Bulletin 10: 35-41.

SAS Institute Inc. 1997. SAS/SATa user's guide, version 6.08, vol.2. SAS Institute Inc. Cary, NC. 846 pp.

Salas, C.; Moya, R. 2014. Kiln, solar and air-drying behavior of lumber of Tectona grandis and Gmelina arborea from fast-grown plantations: moisture content, wood color and drying defects. Drying Technology 32(3) 301-310.

Serrano, R.; Moya, R. 2012. Procesamiento, uso y mercado de la madera en Costa Rica: aspectos históricos y análisis crítico. Revista Forestal Mesoamericana 9(21): 1-12.

Taylor, A.; Gartner, B.; Morrell, J. 2002. Heartwood formation and natural durability: review. Wood Fiber Science 34: 587-611.

Zobel, B.; Sprague, J.R. 1998. Juvenile wood in forest trees. Springer Verlag, New York, USA.

Zobel, B.; Van Buijtenen, B. 1989. Wood variation: its causes and control. Springer, New York, USA. 